\title{
Critical control points and food pathogen presence in dairy plants from Turkey
}

\author{
Oktay TOMAR ${ }^{1 *}$, Gökhan AKARCA ${ }^{1}$
}

\begin{abstract}
Abtract
In the present study, total aerobic mesophilic bacteria count, Staphylococcus aureus and Escherichia coli 0:157 H:7 bacteria count, and presence of bacteria from Listeria and Salmonella genera were determined in the samples collected during separate 5-month-long periods from 15 separate points at five different dairy plants operating in different regions of Turkey. Walls and floors especially, raw material and end-product transport vehicles, tools and materials used in production and product packaging, and storage environments in some dairy plants were heavily loaded with bacteria. Among these microorganisms, the presence of Staphylococcus aureus and Escherichia coli 0:157 H:7 and food pathogens from Listeria and Salmonella genera in these environments can lead to microbiological quality loss and a range problems, including adverse effects on human health. The results of this study are of great importance in determining the lack of personal hygiene among plant personnel, violation of hygiene and sanitation rules, and the lack of quality management systems such as the HACCP (Hazard Analysis Critical Control Point).
\end{abstract}

Keywords: food pathogens; dairy factory; critical control points; hygiene conditions.

Practical Application: This study, contains important data especially for revealing hygienic conditions of medium and small sized dairy factories of Turkey. When the results of the study are examined; It is clear that, hygiene and sanitation rules are not respected as necessary during production and post-production.

\section{Introduction}

The programs implemented in many developed countries often aim at increasing production rather than improving milk safety; however, the control of bacterial content of raw milk is of great importance to public health (Barbano et al., 2006).

Following the emergence of numerous diseases that result from dairy consumption, the microbiological quality of milk and dairy products has become a major issue (De Buyser et al., 2001). There have been reports of epidemics originating from dairies both in the USA and in Europe (Heuvelink et al., 2009). Many studies have shown that raw milk contains pathogens of food origin. Bacteria from Salmonella, Staphylococcus, Bacillus, Escherichia coli O:157 H:7, Campylobacter and Listeria genera are among the pathogenic microorganisms that contaminate milk and dairy products they rank in first place among the sources of salmonella infections in humans (Malorny et al., 2013). Similarly, studies have shown that the presence of Listeria monocytogenes in cheese produced from raw milk varied between $1 \%$ and $22 \%$ (McLauchlin, 1987; Banwart, 1983; Guenther \& Loessner, 2011).

In Europe, $1.5 \%$ of food poisonings of bacterial origin since 1980 have resulted from milk and dairy products. Of the poisonings, milk was responsible for $39 \%$, cheese for $53.1 \%$, and other dairy products for 7.8\% (Bean \& Griffin, 1990). Based on data from the World Health Organization (WHO), foodborne diseases are increasing and pose a serious threat to public health, both in developed and in underdeveloped countries. It was reported that, in 2005, 1.8 million people died from foodborne diseases. Many, perhaps the majority, of these cases were caused by infected milk and dairy products (World Health Organization, 2007). It is known that milk and dairy products are responsible for $8.3 \%$ of organism-originated food poisoning incidents (Greig \& Ravel, 2009).

The data on the risks factors that lead to foodborne diseases have shown that the most of the cases stemmed from faulty application of food processing. The lack of personal hygiene among food workers is the most frequently reported cause of foodborne diseases. Hand hygiene and the poor sanitation level of working surfaces are among the most important sources of contamination. In many countries, despite improvements in hygiene and sanitation standards, advanced food processing applications, the increasing number of educated food processors and conscious consumers, foodborne diseases still pose a threat to public health (Domínguez et al., 2002).

Regarding all the member countries of the European Union, with the regulation put in force on January 1, 2006, hygiene and food safety criteria in food production processes were to be assessed. Based on this enforcement, food products in five different categories (meat and meat products, milk and dairy products, egg products, water products, and fruits and vegetables) are to be identified by six different threat categories: Salmonella spp., Listeria monocytogenes, Staphylococcal enterotoxins, Cronobacter sakazakii, Escherichia coli, and histamines (Hennekinne et al., 2015). 
In Turkey, food safety violations continue to cause serious problems. In 1999, inspections of the Ministry of Health showed that $7.4 \%$ of the investigated food materials, $7.9 \%$ of food production sites, and $6.8 \%$ of food-selling locations were in violation of the EU regulations (Turkey, 2001).

Based on data from 2009, 25,000 typhoid, 28,000 dysentery, 510,000 gastrointestinal infections, 18,000 Hepatitis A, and 12,000 Malta fever cases were reported as health issues that arose from ignoring food safety rules. Since 2001, 324 food poisoning cases that involved death were reported. The number of the patients who received chronic toxicity treatment is unknown . Foodborne risks are separately evaluated based on individual food processes from production to consumption, including processing, transport, storage, purchasing, conservation, preparation, and cooking; these are then classified as physical, chemical, and biological risks (Giray \& Soysal, 2007). To produce healthy food materials, one of the most important parts of the food process from producer to consumer is that the personnel working in food establishments are properly educated in personal cleanliness, hygiene, and sanitation rules (Uğur et al., 1999). Foods can easily be contaminated by various pathogens and through different pathways, and especially through the habits of personnel working in packaging, storage, and sales. These conditions play an important role in foodborne infections and intoxications. The most important step that guarantees hygiene and sanitation in food production is personal hygiene of the persons involved (Atasever, 2000). One study reported that $60 \%$ of the personnel working in food establishments in Turkey did not wash their hands, and that $25-40 \%$ of foodborne diseases were caused by workers in food processing and delivery services (Ünlütürk \& Turantaş, 2014).

Different food materials are affected by different food pathogens. Staphylococcus, Streptococcus, Salmonella, Escherichia coli, Listeria, Mycobacterium tuberculosis, Brucella, Poliovirus, Hepatitis A, and Toxoplasma genera are among the microorganisms that pose risks to milk and dairy products. The counts and/or presence of these microorganisms in foods can be reduced and/or eliminated through proper food safety measures (Kılıç, 2010).

The present study investigated the compliance of workers in the dairy plants operating in Turkey with general hygiene and sanitation rules.

\section{Materials and methods}

\subsection{Sample collection}

In the present study, two parallel samples were collected with sterile swabs from 15 separate points at five different dairy plants during 5-month-long separate periods. The swabs were placed in tubes, each of which contained $10 \mathrm{~mL}$ pre-enrichment medium comprising Listeria Enrichment Broth (LEB, Oxoid CM863+SR142), 0.1\% sterile buffered peptone water (BPW, Oxoid CM 0509) and 2 vial Preston Selective Supplement added Nutrient Broth No.2 (Oxoid CM0067) (Akkaya \& Alışarlı, 2006). The swab samples were brought to the laboratory under cold chain conditions.

\subsection{Total Aerobic Mesophilic Bacteria Count (TAMBC)}

Total aerobic mesophilic bacteria counts were determined after a $24-48 \mathrm{~h}$ incubation under aerobic conditions at $37{ }^{\circ} \mathrm{C}$ using Plate Count Agar (PCA) (Merck, 105463) (Association of Official Analytical Chemists, 2006).

\subsection{Staphylococcus aureus count}

Staphylococcus aureus counts were determined after 45-47 h incubation under aerobic conditions at $35^{\circ} \mathrm{C}$ and using Baird-Parker agar (Merck, 105406) (Bennett \& Lancette, 2001; Martins et al., 2009).

\subsection{Isolation of bacteria from Listeria genus}

Tubes containing $10 \mathrm{~mL}$ Listeria Enrichment Broth (LEB) were incubated under aerobic conditions at $30^{\circ} \mathrm{C}$ for 24 hours. Following the incubation, $0.1 \mathrm{~mL}$ of LEB was transferred using sterile swabs to tubes containing $10 \mathrm{~mL}$ sterile Fraiser Broth (Oxoid, CM895+SR156) and incubated at $35^{\circ} \mathrm{C}$ for 48 hours. After the incubation was completed, $0.1 \mathrm{~mL}$ of samples were streaked on PALCAM Agar (Oxoid, CM 877+SR150) and Oxford Agar (Oxoid, CM 856+SR140); both mediums were then incubated at $30^{\circ} \mathrm{C}$ for 48 hours. Following the incubation, 5 of the colonies that grew on each petri dish that were suspected to be Listeria species were transferred to Trypticase Soy Yeast Agar for biochemical analysis (TSA-YE, Difco, 0370). The colonies that grew on the plates after incubation at $30{ }^{\circ} \mathrm{C}$ for $24-48$ hours were tested using Gram staining, methyl red staining, the Voges-Proskauer reaction, nitrite reduction; for catalase and oxidase using $3 \% \mathrm{H}_{2} \mathrm{O}_{2}$; motility using SIM (Sulfide-Indole-Motility) medium; and beta hemolysis using blood agar. The Gram-positive, catalase-positive, oxidase-negative bacteria that showed umbrella-shaped growth during 7 days in SIM medium at $25^{\circ} \mathrm{C}$ and showed beta hemolysis on blood agar were identified as Listeria spp. (Akkaya \& Alışarlı, 2006; International Organization for Standardization, 1996).

\subsection{Salmonella spp. isolation}

The tubes containing $10 \mathrm{~mL}$ sterile buffered peptone water (BPW) (Oxoid, CM 0509) and swabs were incubated at $37^{\circ} \mathrm{C}$ for 24 hours. Following the incubation, $0.1 \mathrm{~mL}$ of the pre-enriched medium was transferred to the tubes containing $10 \mathrm{~mL}$ Rappaport-Vassiliadis soya peptone broth (RVS) (Oxoid, CM 0866). In addition, $1 \mathrm{~mL}$ of the same medium was also transferred to tubes containing $10 \mathrm{~mL}$ sterile Muller-Kauffmann tetrathionate/novabiocin broth (MKTTn) (Oxoid, CM 1048). The RVS-containing tubes and MKTTn-containing tubes were incubated for 24 hours at $43^{\circ} \mathrm{C}$ and $37^{\circ} \mathrm{C}$, respectively. After the incubation, a loopful of medium from both tubes were inoculated into xylose lysine deoxycholate agar (XLD) (Oxoid, CM 469) and brilliant green agar (BGA) (Oxoid, CM 0329). Following inoculation, both agars were incubated in a drying oven at $37^{\circ} \mathrm{C}$ for 24 hours. After incubation, black-centered and pink-colored colonies that grew on the XLD agar, and pink and transparent colonies that grew on the BGA agar, were deemed suspicious; at least 3 of these colonies were transferred to nutrient agar (Oxoid, $\mathrm{CM} 0003$ ) and incubated at $37^{\circ} \mathrm{C}$ for 24 hours (International Organization for Standardization, 2002). For biochemical tests, 
the colonies that grew on the nutrient agar were transferred to slant agars comprising Triple sugar iron agar (TSIA) (Oxoid, CM 277) and lysine iron agar (LIA) (Oxoid, CM 381) and incubated at $37^{\circ} \mathrm{C}$ for 24 hours. The tubes that showed color changes were deemed positive (Flowers et al., 1992).

\subsection{Biochemical tests}

The IMViC (indol, methyl red, Voges-Proskauer, citrate) test, $\mathrm{H}_{2} \mathrm{~S}$ production, urease test, citrate use, ability to ferment glucose, lactose, maltose, arabinose, sorbitol, mannitol and dulcitol, and Gram staining tests were applied to all suspicious colonies. The suspicious colonies were tested for agglutination using Salmonella antiserum (Salmonella O Poly A-1 and Vi-Difco 2264-47-2). The colonies that showed agglutination were deemed positive (International Organization for Standardization, 2002).

\subsection{Escherichia coli 0:157 H:7 isolation}

The tubes containing $9 \mathrm{~mL}$ sterile TSB (Tryptic Soy Broth) with added Novobiocin (Oxoid, CM0989) were incubated at $37^{\circ} \mathrm{C}$ for $24 \mathrm{~h}$; a loopful of culture was then transferred to SMAC (Sorbitol-MacConkey) agar (Oxoid, CM0981) and incubated at $37^{\circ} \mathrm{C}$ for $18 \mathrm{~h}$. The isolated O157: $\mathrm{H} 7$ colonies were tested in accordance with the instructions provided by the manufacturer (Feng \& Weagant, 2002).

\section{Results and discussion}

In the present study, TAMB and Staphylococcus aureus counts and the presence of bacteria from Listeria, Salmonella spp. and Escherichia coli 0:157 H:7 genera in the samples collected with sterile swabs and taken from 15 points in 5 different dairy plants ( $\mathrm{A}, \mathrm{B}, \mathrm{C}, \mathrm{D}$ and $\mathrm{E}$ ) operating in different regions of Turkey were determined. The resultant bacteria counts with respect to the locations of the samples are given in the Table 1 to 5 .

Table 1. Total Aerobic Mesophilic Bacteria Count in five different dairy plants (A-E) $\left(\log \mathrm{cfu} / \mathrm{cm}^{2}\right)$.

\begin{tabular}{|c|c|c|c|c|c|c|}
\hline Samples & Number of Total Sample & A & B & $\mathrm{C}$ & D & $\mathbf{E}$ \\
\hline Floor & 200 & $8.3 \pm 0.7$ & $7.7 \pm 0.58$ & $8.8 \pm 1.7$ & $7.5 \pm 1.08$ & $10.1 \pm 1.7$ \\
\hline Walls & 200 & $6 \pm 1$ & $6.3 \pm 1.58$ & $6 \pm 2$ & $4.7 \pm 1.57$ & $7.3 \pm 1.7$ \\
\hline Used Water & 20 & $3.1 \pm 0.7$ & $3.5 \pm 16$ & $3.7 \pm 1$ & $3.1 \pm 0.62$ & $4.6 \pm 1.2$ \\
\hline Cooling Water & 20 & $3.5 \pm 0.6$ & $3.2 \pm 0.44$ & $3.8 \pm 0.7$ & $3.6 \pm 0.63$ & $4.2 \pm 0.6$ \\
\hline Blades & 200 & $5 \pm 1$ & $4.2 \pm 1.01$ & $4 \pm 1.5$ & $3.4 \pm 1.26$ & $3.9 \pm 1.2$ \\
\hline Cheese Cutter & 200 & $3.7 \pm 0.7$ & $3.6 \pm 0.70$ & $3.7 \pm 0.5$ & $4 \pm 0.88$ & $4.1 \pm 0.8$ \\
\hline Cheese Ruller & 200 & $4.1 \pm 0.6$ & $4 \pm 0.40$ & $4.1 \pm 0.8$ & $3.8 \pm 1.01$ & $5.0 \pm 1.1$ \\
\hline Cheese Boats & 200 & $2.9 \pm 0.6$ & $4.1 \pm 0.44$ & $4.5 \pm 0.8$ & $3.9 \pm 0.44$ & $3.9 \pm 1.0$ \\
\hline Tanks & 200 & $4.3 \pm 0.7$ & $4.8 \pm 17$ & $4.2 \pm 0.6$ & $3.9 \pm 0.6$ & $5.9 \pm 1.2$ \\
\hline Carriages & 200 & $7 \pm 1$ & $4.7 \pm 0.89$ & $4.4 \pm 0.6$ & $6.4 \pm 0.6$ & $7.4 \pm 1.0$ \\
\hline Filling Line & 20 & $3.6 \pm 0.7$ & $3 \pm 0.54$ & $3.4 \pm 0.4$ & $3.7 \pm 0.4$ & $4.0 \pm 0.3$ \\
\hline Packing Unit & 200 & $5.6 \pm 0.8$ & $5.1 \pm 0.56$ & $5.5 \pm 0.7$ & $4.5 \pm 0.3$ & $6.7 \pm 0.8$ \\
\hline Cold Storage Corridors & 200 & $8.1 \pm 0.7$ & $6.8 \pm 0.75$ & $7.4 \pm 0.8$ & $7.6 \pm 0.8$ & $9.3 \pm 0.7$ \\
\hline Cold Storage Walls & 200 & $6 \pm 1$ & $4.8 \pm 0.66$ & $6.9 \pm 0.7$ & $6.2 \pm 0.8$ & $6.9 \pm 0.7$ \\
\hline Cold Storage Shelves & 200 & $6.7 \pm 0.7$ & $6.8 \pm 0.58$ & $6.8 \pm 0.5$ & $5.9 \pm 0.5$ & $6.9 \pm 0.9$ \\
\hline
\end{tabular}

Table 2. Staphylococcus aureus Counts in five different dairy plants (A-E) (log cfu/ $\left.\mathrm{cm}^{2}\right)$.

\begin{tabular}{|c|c|c|c|c|c|c|}
\hline Samples & Number of Total Sample & A & B & $\mathrm{C}$ & D & $\mathbf{E}$ \\
\hline Floor & 200 & $5.6 \pm 0.9$ & $5.6 \pm 1$ & $5.9 \pm 1.6$ & $5.3 \pm 1.6$ & $7.2 \pm 1.9$ \\
\hline Walls & 200 & $3.4 \pm 0.7$ & $4.2 \pm 1.2$ & $3.8 \pm 1$ & $3.2 \pm 0.6$ & $5.1 \pm 1.1$ \\
\hline Used Water & 20 & ND & ND & ND & ND & $1.6 \pm 1.4$ \\
\hline Cooling Water & 20 & $\mathrm{ND}$ & ND & ND & ND & $2.27 \pm 1.5$ \\
\hline Blades & 200 & ND & ND & ND & ND & ND \\
\hline Cheese Cutter & 200 & ND & ND & ND & ND & $1.22 \pm 1.37$ \\
\hline Cheese Ruller & 200 & ND & ND & ND & ND & $1.45 \pm 1.30$ \\
\hline Cheese Boats & 200 & ND & ND & ND & ND & ND \\
\hline Tanks & 200 & ND & $1.3 \pm 1.1$ & ND & ND & $2.3 \pm 0.5$ \\
\hline Carriages & 200 & $2.1 \pm 1.1$ & $1.0 \pm 1.2$ & ND & $2.1 \pm 0.5$ & $2.3 \pm 0.4$ \\
\hline Filling Line & 20 & ND & ND & $\mathrm{ND}$ & ND & ND \\
\hline Packing Unit & 200 & $2.2 \pm 0.5$ & $1.2 \pm 1$ & $1.6 \pm 1.1$ & ND & $2.2 \pm 0.3$ \\
\hline Cold Storage Corridors & 200 & $2.5 \pm 0.5$ & $2.4 \pm 1.5$ & $2.2 \pm 0.2$ & $2.4 \pm 0.4$ & $2.5 \pm 0.6$ \\
\hline Cold Storage Walls & 200 & $2.1 \pm 0.6$ & $2.1 \pm 0.4$ & $2.6 \pm 0.5$ & $2.3 \pm 0.4$ & $2.6 \pm 0.3$ \\
\hline Cold Storage Shelves & 200 & $2.2 \pm 0.4$ & $1.4 \pm 0.9$ & $1.6 \pm 1.7$ & ND & $2.4 \pm 0.3$ \\
\hline
\end{tabular}


Table 3 . Number and spread of bacterial strains of Listeria in five different dairy plants (A-E).

\begin{tabular}{|c|c|c|c|c|c|c|c|c|c|c|c|}
\hline \multirow{2}{*}{ Samples } & \multirow{2}{*}{ Number of Total Sample } & \multicolumn{2}{|c|}{ A } & \multicolumn{2}{|c|}{ B } & \multicolumn{2}{|c|}{ C } & \multicolumn{2}{|c|}{ D } & \multicolumn{2}{|c|}{ E } \\
\hline & & $\mathbf{n}$ & $\%$ & $\mathbf{n}$ & $\%$ & $\mathbf{n}$ & $\%$ & $\mathbf{n}$ & $\%$ & $\mathbf{n}$ & $\%$ \\
\hline Floor & 200 & 4 & 2 & 6 & 3 & 5 & 2.5 & 6 & 3 & 6 & 3 \\
\hline Walls & 200 & 2 & 1 & 1 & 0.5 & 2 & 1 & 2 & 1 & 5 & 2.5 \\
\hline Used Water & 20 & 0 & 0 & 0 & 0 & 0 & 0 & 0 & 0 & 0 & 0 \\
\hline Cooling Water & 20 & 0 & 0 & 0 & 0 & 0 & 0 & 0 & 0 & 0 & 0 \\
\hline Blades & 200 & 1 & 0.5 & 2 & 1 & 3 & 1.5 & 3 & 1.5 & 2 & 1 \\
\hline Cheese Cutter & 200 & 0 & 0 & 0 & 0 & 0 & 0 & 0 & 0 & 2 & 1 \\
\hline Cheese Ruller & 200 & 0 & 0 & 0 & 0 & 1 & 0.2 & 1 & 0.5 & 2 & 1 \\
\hline Cheese Boats & 200 & 0 & 0 & 0 & 0 & 0 & 0 & 0 & 0 & 0 & 0 \\
\hline Tanks & 200 & 0 & 0 & 0 & 0 & 1 & 0.2 & 0 & 0 & 3 & 1.5 \\
\hline Carriages & 200 & 1 & 0.5 & 0 & 0 & 0 & 0 & 1 & 0.5 & 2 & 1 \\
\hline Filling Line & 20 & 0 & 0 & 0 & 0 & 0 & 0 & 0 & 0 & 0 & 0 \\
\hline Packing Unit & 200 & 0 & 0 & 0 & 0 & 1 & 0.5 & 0 & 0 & 2 & 1 \\
\hline Cold Storage Corridors & 200 & 2 & 1 & 0 & 0 & 1 & 0.5 & 2 & 1 & 3 & 1.5 \\
\hline Cold Storage Walls & 200 & 1 & 0.5 & 0 & 0 & 0 & 0 & 0 & 0 & 0 & 0 \\
\hline Cold Storage Shelves & 200 & 0 & 0 & 0 & 0 & 0 & 0 & 0 & 0 & 0 & 0 \\
\hline
\end{tabular}

Table 4. Number and spread of bacterial strains of Salmonella spp. in five different dairy plants (A-E).

\begin{tabular}{|c|c|c|c|c|c|c|c|c|c|c|c|}
\hline \multirow{2}{*}{ Samples } & \multirow{2}{*}{ Number of Total Sample } & \multicolumn{2}{|c|}{$\mathbf{A}$} & \multicolumn{2}{|c|}{ B } & \multicolumn{2}{|c|}{$\mathrm{C}$} & \multicolumn{2}{|c|}{ D } & \multicolumn{2}{|c|}{$\mathrm{E}$} \\
\hline & & $\mathbf{n}$ & $\%$ & $\mathbf{n}$ & $\%$ & $\mathbf{n}$ & $\%$ & $\mathbf{n}$ & $\%$ & $\mathbf{n}$ & $\%$ \\
\hline Floor & 200 & 11 & 5.5 & 10 & 5 & 12 & 6 & 11 & 5.5 & 15 & 7.5 \\
\hline Walls & 200 & 4 & 2 & 5 & 2.5 & 8 & 4 & 2 & 1 & 8 & 4 \\
\hline Used Water & 20 & 0 & 0 & 0 & 0 & 0 & 0 & 0 & 0 & 0 & 0 \\
\hline Cooling Water & 20 & 0 & 0 & 0 & 0 & 0 & 0 & 0 & 0 & 0 & 0 \\
\hline Blades & 200 & 1 & 0.5 & 2 & 1 & 0 & 0 & 0 & 0 & 3 & 1.5 \\
\hline Cheese Cutter & 200 & 0 & 0 & 1 & 0.5 & 0 & 0 & 0 & 0 & 2 & 1 \\
\hline Cheese Ruller & 200 & 2 & 1 & 2 & 1 & 2 & 1 & 1 & 0.5 & 2 & 1 \\
\hline Cheese Boats & 200 & 1 & 0.5 & 0 & 0 & 0 & 0 & 0 & 0 & 2 & 1 \\
\hline Tanks & 200 & 0 & 0 & 0 & 0 & 0 & 0 & 0 & 0 & 4 & 2 \\
\hline Carriages & 200 & 1 & 0.5 & 0 & 0 & 0 & 0 & 1 & 0.5 & 4 & 2 \\
\hline Filling Line & 20 & 0 & 0 & 0 & 0 & 0 & 0 & 0 & 0 & 0 & 0 \\
\hline Packing Unit & 200 & 3 & 1.5 & 3 & 1.5 & 3 & 1.5 & 0 & 0 & 5 & 2.5 \\
\hline Cold Storage Corridors & 200 & 6 & 3 & 4 & 2 & 5 & 2.5 & 6 & 3 & 9 & 4.5 \\
\hline Cold Storage Walls & 200 & 5 & 2.5 & 0 & 0 & 6 & 3 & 1 & 0.5 & 6 & 3 \\
\hline Cold Storage Shelves & 200 & 1 & 0.5 & 0 & 0 & 2 & 1 & 0 & 0 & 4 & 2 \\
\hline
\end{tabular}

Although there are not many studies conducted, in detail, for general hygenic status of dairy process factories in Turkey and worldwide, there are similar researches studied for different food product sections (Shojaei et al., 2006; Sert, 2006; Akkaya et al., 2008, 2011).

In 2011, Akkaya et al. (2011), in their study on Listeria species in fish-selling areas, determined that 1 out of 20 samples (5\%) collected from the workers' hands contained Listeria ivanovii. In 2006, Shojaei et al. (2006), determined that $72.7 \%$ of the 150 samples collected from the personnel working in the food establishments operating in Iran were contaminated. Sert, in their study carried out in 2006, determined that the work clothes of the personnel working in the kitchens of 3 out of 5 hospitals (60\%) were not in proper condition.

In their study on Escherichia coli O157:H7/O157, Listeria monocytogenes and Salmonella spp. presence on the equipment and workers in cattle slaughterhouses, Akkaya et al. (2008) reported that Listeria monocytogenes and Salmonella spp. presence in these areas posed a greater risk than E. coli O157:H7.

In another study on fresh fish and fish-selling areas in Turkey, Akkaya et al. (2011) reported Listeria monocytogenes presence in 1 out of 20 samples (5\%) collected from the boots of workers.

Van Kessel et al. (2004) reported that foodborne pathogen ratios in milk storage tanks were $6.5 \%$ Listeria monocytogenes and 2.6\% Salmonella spp. Similarly, Jayarao \& Henning (2001) reported that, in milk storage tanks, these ratios were $4.6 \%$, $6.1 \%$, and $9.2 \%$ for Listeria monocytogenes, Salmonella spp, and Campylobacter jejuni, respectively.

Temelli et al. (2006), in their study carried out in 2 butcher shops and hypermarkets and 2 dairy farms and milk factories, determined that Escherichia coli was present on the personnel 
Table 5. Number and spread of bacterium of Escherichia coli O:157 H:7 in five different dairy plants (A-E).

\begin{tabular}{|c|c|c|c|c|c|c|c|c|c|c|c|}
\hline \multirow{2}{*}{ Samples } & \multirow{2}{*}{ Number of Total Sample } & \multicolumn{2}{|c|}{$\mathbf{A}$} & \multicolumn{2}{|c|}{ B } & \multicolumn{2}{|c|}{ C } & \multicolumn{2}{|c|}{ D } & \multicolumn{2}{|c|}{ E } \\
\hline & & $\mathbf{n}$ & $\%$ & $\mathbf{n}$ & $\%$ & $\mathbf{n}$ & $\%$ & $\mathbf{n}$ & $\%$ & $\mathbf{n}$ & $\%$ \\
\hline Floor & 200 & 0 & 0 & 0 & 0 & 0 & 0 & 0 & 0 & 0 & 0 \\
\hline Walls & 200 & 0 & 0 & 0 & 0 & 0 & 0 & 0 & 0 & 0 & 0 \\
\hline Used Water & 20 & 0 & 0 & 0 & 0 & 0 & 0 & 0 & 0 & 0 & 0 \\
\hline Cooling Water & 20 & 0 & 0 & 0 & 0 & 0 & 0 & 0 & 0 & 0 & 0 \\
\hline Blades & 200 & 0 & 0 & 0 & 0 & 0 & 0 & 0 & 0 & 0 & 0 \\
\hline Cheese Cutter & 200 & 0 & 0 & 0 & 0 & 0 & 0 & 0 & 0 & 0 & 0 \\
\hline Cheese Ruller & 200 & 0 & 0 & 0 & 0 & 0 & 0 & 0 & 0 & 0 & 0 \\
\hline Cheese Boats & 200 & 0 & 0 & 0 & 0 & 0 & 0 & 0 & 0 & 0 & 0 \\
\hline Tanks & 200 & 0 & 0 & 0 & 0 & 0 & 0 & 0 & 0 & 0 & 0 \\
\hline Carriages & 200 & 0 & 0 & 0 & 0 & 0 & 0 & 0 & 0 & 0 & 0 \\
\hline Filling Line & 20 & 0 & 0 & 0 & 0 & 0 & 0 & 0 & 0 & 0 & 0 \\
\hline Packing Unit & 200 & 0 & 0 & 0 & 0 & 0 & 0 & 0 & 0 & 0 & 0 \\
\hline Cold Storage Corridors & 200 & 0 & 0 & 0 & 0 & 0 & 0 & 0 & 0 & 1 & 0.5 \\
\hline Cold Storage Walls & 200 & 0 & 0 & 0 & 0 & 0 & 0 & 0 & 0 & 0 & 0 \\
\hline Cold Storage Shelves & 200 & 0 & 0 & 0 & 0 & 0 & 0 & 0 & 0 & 0 & 0 \\
\hline
\end{tabular}

working in feta cheese production. The Escherichia coli ratios found on workers in butcher shops and dairy farms were $37.5 \%$ and $28.5 \%$, respectively, whereas Escherichia coli levels of hypermarket and milk factory workers were below detectable levels.

Akkaya \& Alşsarlı (2006) investigated the Listeria monocytogenes and Salmonella spp. presence and prevalence in 100 feta cheese samples bought from district bazaars located in the Afyonkarahisar city center and reported that Listeria monocytogenes was present in $6 \%$ of the samples (6/100) and Salmonella spp. was present in $2 \%(2 / 100)$ of the samples.

The results obtained in our study and the results of similar relevant studies showed that most food production plants were deficient in hygiene and sanitation, and that workers in these plants did not conform to personal hygiene and general hygiene rules. This problem might be caused by careless acts of employees and employers towards hygiene and lacks in education.

\section{Conclusion}

In the present study, the compliance of five different dairy plants operating in Turkey with hygiene and sanitation rules was investigated; the high levels of microorganisms, especially on the walls and floors of some plants, indicated that sufficient and proper cleaning and disinfection practices were not implemented in these plants. These are the regions that carry the highest risk of contamination in factories and are of great importance in terms of microorganism contamination in products (raw or processed).

Clearly, in dairy factories, the transport vehicles used to transport end-products including cheese, goat's cheese and yoghurt, and the tools and materials used in cheese production (cheese trays, cheese rulers, knives, etc.) contained extremely high levels of microorganisms because these vessels were not regularly and properly cleaned or sterilized. This can lead to serious problems, including quality loss in end-products resulting from secondary contamination after production, shortened shelf lives, brand value losses, being subjected to formal sanctions, and having a negative effect on consumer health. The presence of severe food pathogens, particularly Listeria, Salmonella, and Escherichia coli, add to the severity of the situation.

The results obtained in the samples taken from the end-product packaging lines showed that, in some dairy plants, the workers in the packaging lines and tools and equipment used in these areas had extremely low hygienic quality. The extremely poor results obtained in parts of the production and marketing process such as packaging, where hygiene is of utmost importance, is a clear sign of a possible threat. The overgrowth of human-borne pathogens such as Staphylococcus aureus in these areas indicated that the workers did not pay attention to personal hygiene.

To repeat, the extremely low microbiological quality of cold storage corridors and, especially, inner-storage walls of some dairy plants showed that hygiene and sanitation rules were almost completely disregarded; the cool temperatures in these areas, unlike in other areas of the factories, have led workers to believe that "microorganism growth is inhibited in these areas" and therefore, the required cleaning and disinfection procedures were not followed. However, it should not be forgotten that dangerous food pathogens such as Listeria and psychrophilic and psychotropic bacteria that adversely affect human health can easily grow under low temperatures and cause serious problems. These areas, which are in contact with end-products, can cause microbiological quality loss and consequently lead to various problems, especially in human health.

Detailed results, obtained from 5 different dairy factories established in Turkey, give information about general hygiene and sanitation problems faced in dairy factories. This study points out especially the places, with highest microbial loads and contamination risks. These places with high risk should be included in HACCP and regular analysis and inspection of these points must be conducted more frequently. Thus, cleaning and disinfection of these places must be considered more. Since possible contaminations in the dairy working area and dairy staff bodies can be prevented, dairy products will be more safe to consume for human health and the microbiological quality of 
these products will be increased. Thus, shelf lives of products can be prolonged due to the decrease in microbial load of products.

In conclusion, based on current studies, workers in dairy plants should receive education on basic hygiene and sanitation rules, to give them a sense of the gravity of the situation. The HACCP system and Good Manufacture Practices (GMP) should be established in all the processes carried out in dairy plants, from raw material processing to end-product production. Moreover, planned and regular cleaning of these plants is of great importance to minimize the risk of possible contaminations. It is evident that, in this way, the possibility of contamination in production of dairy products will be reduced, microbiological quality. Consequently, the shelf-life of the products will be improved and human health will not be put at risk, especially of food poisoning.

In addition, obtained results can be helpful for workers to overcome the problems faced in dairy factories. This study can be enlightening for further studies, related to dairy products.

\section{References}

Akkaya, L., \& Alışarlı, M. (2006). Consumption presented in Afyonkarahisar cheese Listeria monocytogenes and Salmonella spp. determination of existence. YYU Veterinary Faculty Journal., 17(1-2), 87-91.

Akkaya, L., Alişarlı, M., Çetinkaya, Z., Kara, R., \& Telli, R. (2008). Occurrence of Escherichia coli O157:H7/O157, Listeria monocytogenes and Salmonella spp. in beef slaughterhouse environments, equipment and workers. Journal of Muscle Foods, 19(3), 261-274. http://dx.doi. org/10.1111/j.1745-4573.2008.00108.x.

Akkaya, L., Atabey, H. İ., Gok, V., \& Kara, R. (2011). Detection of Listeria species in fresh fish and fish market environment by IMS Technique in Turkey. Archiv fur Lebensmittelhygiene, 62, 16-19.

Association of Official Analytical Chemists - AOAC. (2006). Official methods of analysis of the Association of Official Analytical Chemists: method 966.23 (18th ed.) Gaithersburg: AOAC.

Atasever, M. (2000). Hygiene in food is places, preparation and conservation of foods. Veterinary Faculty Journal, 11(2), 117-122.

Banwart, G. J. (1983). Basic food microbiology. Westport: Avi Publishing Company.

Barbano, D. M., Ma, Y., \& Santos, M. V. (2006). Influence of raw milk quality on fluid milk shelf life. Journal of Dairy Science, 89(Suppl 1), E15-E19. http://dx.doi.org/10.3168/jds.S0022-0302(06)72360-8. PMid:16527874.

Bean, N. H., \& Griffin, P. M. (1990). Foodborne disease outbreaks in the United States, 1973-1987: pathogens, vehicles, and trends. Vehiclesand Trends Jornal of Food Protection, 53(9), 804. http:// dx.doi.org/10.4315/0362-028X-53.9.804.

Bennett, R. W., \& Lancette, G. A. (2001). Staphylococcus aureus: bacteriological analytical manual online (chap. 12). USA: U.S. Food \& Drug Administration Center for Food Safety \& Applied Nutrition.

De Buyser, M.-L., Dufour, B., Maire, M., \& Lafarge, V. (2001). Implication of milk and milk products in food-borne disease in France and different industrialized countries. International Journal of Food Microbiology, 67(1-2), 1-17. http://dx.doi.org/10.1016/S01681605(01)00443-3. PMid:11482557.

Domínguez, C., Gómez, I., \& Zumalacárregui, J. (2002). Prevalence of Salmonella and Campylobacter in Retail Chicken Meat in Spain. International Journal of Food Microbiology, 72(1-2), 165-168. http:// dx.doi.org/10.1016/S0168-1605(01)00638-9. PMid:11843408.
Feng, P., \& Weagant, S. D. (2002). Diarrheagenic Escherichia coli: bacteriological analytical manual online (chap. 4A). College Park: FDA.

Flowers, R. S., D’aust, J. Y., Andrews, W. H., \& Bailey, J. S. (1992). Salmonella. In C. Vanderzant \& D. F. Spilttstoesser (Eds.), Compendium of the methods for the microbiological examinations of foods (pp. 371-422). Washington: American Public Health Assocition.

Giray, H., \& Soysal, A. (2007). Food safety and legislation in Turkey. Turk Silahli Kuvvetleri Koruyucu Hekimlik Bulteni, 6(6), 485-490.

Greig, J. D., \& Ravel, A. (2009). Analysis of foodborne outbreak data reported internationally for source attribution. International Journal of Food Microbiology, 130(2), 77-87. http://dx.doi.org/10.1016/j. ijfoodmicro.2008.12.031. PMid:19178974.

Guenther, S., \& Loessner, M. J. (2011). Bacteriophage biocontrol of Listeria monocytogenes on soft ripened white mold and red-smear cheeses. Bacteriophage, 1(2), 94-100. http://dx.doi.org/10.4161/ bact.1.2.15662. PMid:22334865.

Hennekinne, J. A., Herbin, S., Firmesse, O., \& Auvray, F. (2015). European food poisoning outbreaks involving meat and meat based products. Procedia Food Science, 5, 93-96. http://dx.doi.org/10.1016/j. profoo.2015.09.024.

Heuvelink, A. E., Van Heerwaarden, C., Zwartkruis-Nahuis, A., Tilburg, J. J., Bos, M. H., Heilmann, F. G., Hofhuis, A., Hoekstra, T., \& de Boer, E. (2009). Two outbreaks of campylobacteriosis associated with the consumption of raw cow's milk. International Journal of Food Microbiology, 134(1-2), 70-74. http://dx.doi.org/10.1016/j. ijfoodmicro.2008.12.026. PMid:19167125.

International Organization for Standardization - ISO. (1996). ISO 11290 1,2: horizontal method for the detection of Listeria monocytogenes. Switzerland: ISO.

International Organization for Standardization - ISO. (2002). ISO 65791: microbiology of food and animal feeding stuffs: horizontal method for the detection of Salmonella spp. Switzerland: ISO.

Jayarao, B. M., \& Henning, D. R. (2001). Prevalence of foodborne pathogens in bulk tank milk. Journal of Dairy Science, 84(10), 2157-2162. http://dx.doi.org/10.3168/jds.S0022-0302(01)74661-9. PMid:11699446.

Kilıç, S. (2010). Dairy microbiology. İzmir: Sidaş Press.

Malorny, B., Mäde, D., \& Löfström, C. (2013). Real-time PCR detection of foodborne pathogenic Salmonella spp. In D. Rodríguez-Lazaro (Ed.), Real-time PCR in food science current technology and applications (pp. 57-78). United Kingdom: Horizon Scientific Press.

Martins, I. M., Kabuki, D. Y., \& Kuaye, A. Y. (2009). Determination and characteriztion of pathogens found in dairy products. Revista do Instituto de Medicina Tropical de Adolfo Lutz, 68(3), 359-365.

McLauchlin, J. (1987). Listeria monocytogenes, recent advances in the taxonomy and epidemiology of listeriosis in humans. Journal of Applied Bacteriology, 63(1), 1-11. http://dx.doi.org/10.1111/j.1365-2672.1987. tb02411.x. PMid:3115937.

Sert, Ş. T. (2006). A research on the determination of kitchen personnel hygiene in hospitals in Edirne (Master thesis). Department of Food Engineering, Trakya University Graduate School of Natural and Applied Sciences, Tekirdağ, Turkey.

Shojaei, H., Shooshtaripoor, J., \& Amiri, M. (2006). Efficacy of simple hand-washing in reduction of microbial hand contamination of iranian food handlers. Food Research International, 39(5), 525-529. http://dx.doi.org/10.1016/j.foodres.2005.10.007.

Temelli, S., Cem Şen, M. K., \& Anar, Ş. (2006). Evaluation of hygienic condition of the staff hands working in meat shredding units and white cheese production. Journal of Faculty Veterinary Medicine, 24(1-4), 75-80. 
Turkey. (2001). Everyone health, Turkey's goals and strategies. Ankara: Ministry of Health.

Uğur, M., Nazlı, B., \& Bostan, K. (1999). Food hygiene. İstanbul: Teknik Press.

Ünlütürk, A., \& Turantaş, F. (2014). Food microbiology (4th ed.). İzmir: Mengi Tan Press.
Van Kessel, J. S., Karns, J. S., Gorski, L., McCluskey, B. J., \& Perdue, M. L. (2004). Prevalence of Salmonellae, Listeria monocytogenes and fecal coliforms in bulk tank milk on U.S. dairies. Journal of Dairy Science, 87(9), 2822-2830. http://dx.doi.org/10.3168/jds.S00220302(04)73410-4. PMid:15375040.

World Health Organization - WHO. (2007). Food safety and foodborne illness. Geneva: WHO. 